AIR COMMAND AND STAFF COLLEGE

AIR UNIVERSITY

\title{
MUSIC AND COMBAT MOTIVATION
}

\author{
by \\ Sally C. Maddocks, Major, USAF \\ Master of Science in Physics \\ Master of Science in Aerospace Engineering
}

A Research Report Submitted to the Faculty

In Partial Fulfillment of the Graduation Requirement for the Degree of

\section{MASTER OF OPERATIONAL ARTS AND SCIENCES}

\author{
Advisor: Dr. John G. Terino
}

Maxwell Air Force Base, Alabama

April 2015 


\section{DISCLAIMER}

The views expressed in this academic research paper are those of the author(s) and do not reflect the official policy or position of the US government or the Department of Defense. In accordance with Air Force Instruction 51-303, it is not copyrighted, but is the property of the United States government. 
Music has the power to influence combat motivation and morale; as a nation, the United States must do a better job capturing and utilizing this powerful tool. There are many historical examples from which to draw evidence of the impact of music on fielded forces. One must study not only the historical events, but also the scientific principles behind motivation and music. Primal human nature drives motivation while music reaches deep into the mind to create decision-affecting moods. With the knowledge of the influence of these factors, many governments intentionally tried to use music to sway enemy soldiers’ morale through propaganda in WWII. Additionally the United States attempted to bolster the motivation and morale of its own troops through music in WWI and WWII. In Vietnam, the US saw music as a tool to improve morale, while little effort went toward developing combat motivation. As technology and social norms evolve, the methods for delivery and the effectiveness of music must evolve as well. The future of music for combat motivation is unknown, and for that reason, must be explored.

Two events capture the attention of history scholars with their overwhelming motivational effects on the soldiers of rival units. During the Civil War, troops from both the North and the South came together through music as their bands and soldiers sang nostalgic songs common to both cultures in unison. In the immediate timeframe following the music, the soldiers wanted to cease hostilities. The music reminded them of home and they simply wished to return to their families. In the longer term, this music solidified their resolve to fight for the ideals that brought them to war initially. ${ }^{1}$ Again, the power of music is visible in a similar way during the Christmas Truce of 1914 in WWI. Soldiers shared a cultural experience, initiated by music, leading to an enduring cease-fire and continued friendly interaction. Leadership coerced the soldiers into continued fighting after the event, although many no longer wished to battle. ${ }^{2}$ 
From these events and a growing understanding of combat motivation, governments began to use music to achieve a military advantage. WWII involved prominent use of music combined with propaganda to attempt to influence enemy morale and motivation. Germany, Japan, Great Britain, France, and the United States all used broadcast media involving music to attempt to influence the outcome of war. Armed with the lessons from WWII, the United States attempted to harness the power of music again to bolster armed forces serving in Vietnam, with little success. It is essential to understand the motivating effects of music on combat troops to gain advantage in future conflicts.

Music has been present in military operations throughout history. Initially music was a utility for movement and maneuver providing a beat to coordinate action. Over time, music evolved to provide some level of unit esprit in addition to pure utility. By the time of the American Revolutionary War, battlefield musicians were usually drummers, buglers, or fifers. ${ }^{3}$ Additionally, many units also had soldiers who brought along folk instruments from home including mostly guitars, violins (fiddles) or other stringed instruments. The personal instruments were purely for entertainment in camp, and they were essential to morale. ${ }^{4}$

Music was extremely important to the context of the American Civil War. The lyrics and melodies reflected societal viewpoints on the war unfolding in everyone's backyards. The popular music of the time found its way to the battlefields and camps though soldier-musicians and regimental bands. Many had picked up the melodies before they enlisted while others learned them from their fellow soldiers. Combatants in the war wrote many of the songs, bringing to life the experiences of the battlefield. "Actual soldiers and sailors [...] wrote of their battles and experiences, or expressed their feelings in more or less finished verse.” ${ }^{\text {}}$ This type of 
music was present in war for entertainment purposes and perhaps had an effect on combat motivation by lowering combat stress and reviving the soldier’s ideals for a brief time.

Regimental bands were officially authorized forces during the American Civil War. The United States War Department sanctioned each infantry and artillery regiment to have a brass band of 24 members while cavalry regiments were limited to 16 members. ${ }^{6}$ The Confederacy had similar provisions for their bands. Encamped in the evenings, the bands would perform whenever possible to entertain their regiment. At various times throughout the war, enemy encampments were quite close and the opposing bands were clearly heard by all. There are several documented occasions of where this situation led to a "battle of the bands.",

The "battles" began with an exchange of patriotic music to rally the troops on each side. The Union band played "Yankee Doodle" and the Confederates answered with their best rendition of "Dixie." There were many more songs played back and forth. Throughout the evening, the songs would become more relaxed and subdued. On three independent, documented occasions, these "battles" had a notable ending. The song "Home, Sweet Home" was sentimental to soldiers on both sides. One regimental band would begin playing and the other would join in. The soldiers on both sides sang together and they reportedly experienced brief moments of joy and relief. The soldiers were ready to end the fighting so they could all go home. $^{8}$

The first of these documented events, happened a few weeks after the Battle of Fredericksburg in December 1862. The enemy army encampments lay on opposite banks of the Rappahannock River and in some locations were less than 500 yards apart. After the regimental bands had played their "battle" songs, the mood transitioned to melodies that were more restful. A Union band began playing “Home, Sweet Home” and Confederate bands joined in. All 
available regimental bands in both armies played the melody together. The soldiers stopped their activities and joined in to sing. Private Frank Mixson from the $1^{\text {st }}$ South Carolina Volunteers described the situation when the song ended by saying "Everyone went crazy.” He described both sides cheering, jumping up and down and throwing their hats into the air. He reflected "had there not been a river between them, the two armies would have met face to face, shaken hands and ended the war on the spot."9 The music had inspired thoughts of peace.

Later that month, on 30 December 1862, on the eve of the Battle of Stones River, a similar event occurred with different participants. A traditional "battle of the bands" occurred on the eve of another conflict to motivate soldiers with patriotic music. Before the evening concluded, both bands together played "Home, Sweet Home." There is not a personal account of the effect on the troop motivation, but it may have been similar to what occurred following the Battle of Fredericksburg earlier in the month. ${ }^{10}$

On the second evening of the Battle of the Spotsylvania Court House, 10 May 1864, a Confederate band began playing hymns, which were echoed by a nearby Union band. After they concluded their hymns, they began to play patriotic music and then closed their performance with collective rendition of "Home, Sweet Home." At the conclusion, both sides were reported to have cheered quite loudly. ${ }^{11}$

The final documented example of "Home, Sweet Home” being shared by enemies occurred between pickets near Winchester, Virginia in the summer of 1864. In some locations, the pickets were only a few feet apart. Both sides were tired from years of fighting and as night fell, the pickets would talk and arrange a cease-fire for the evening to allow everyone to get sleep. Over time, they became familiar with their enemy counterparts and on several occasions, 
each side would sing a few of their favorite songs. They would conclude by lining up together to sing "Home, Sweet Home” and then turn in for a night of good sleep. ${ }^{12}$

Clearly the military leadership believed in the motivating power of the regimental bands when it came to patriotic songs, utility music, and hymns for the soldiers, however, there was a point in the war where Federal officers banned the playing of "Home, Sweet Home.” They assessed that it was not good for motivation. Their specific fear was that the induced homesickness would lead to desertion. However, over time, it appeared to have the opposite effect in strengthening individual resolve and calling on their deep personal determination. The song had a hidden motivation factor in reminding the soldiers of what was important to them and hence, motivating them more strongly to continue. Thoughts of protecting their home, lives and local ideals were subconsciously aroused by the subtleties of this type of nostalgic music. ${ }^{13}$

There are examples, before, during, and after Civil War battles of this musical phenomenon. There exist primary accounts as to how this song in particular effected motivation to fight. These four events are unrelated, without common players, yet they all came to be in a very similar matter. The music brought a commonality and humanity to enemies at war. They were under stress of combat conditions and, for a moment, that stress was lifted. The soldiers now saw their enemy as someone similar to themselves and they began to question the war. Originally, most had voluntarily left their homes to fight for an ideal, to preserve the lifestyle that they valued. Even after conscription was instituted, the reality that the quick and valiant battle they left their homes to fight had become a bloody endless mechanism destroying life all around them changed their feelings toward the conflict even more when the right stimulus was applied. For one moment, they saw the people they were fighting were actually the same as them. 
Nevertheless, this desire to cease hostilities was neither enduring nor was it possible within the constraints of the situation.

The results of the battles before, during, and after these events show no changes in outcomes, casualty rates, or violence (see appendix A). ${ }^{14}$ It is hard to judge if the temporary or lasting effects played into the battle experiences of the individuals or not. Had there been a great effect on individuals no longer wanting to fight after realizing their similarities with their enemy, it would have been nearly impossible to act on it. Desertion would have been a soldier's only chance to cease hostilities and regulation, along with social pressure, would have been a dominating obstacle to overcome in ceasing hostilities. More exploration of primary sources from these events might allow for a deeper review of the motivational effects on the individual soldiers.

An extraordinarily similar event occurred in the trenches of the Western Front in WWI. As Christmas approached, the Germans began placing small tannenbaums on their parapets. Soldiers on both sides stationed on the front lines received packaged Christmas presents from home as well as government provided treats to show appreciation and perhaps improve their unpleasant situation. ${ }^{15}$ All along the trench lines, informal cease-fire agreements started in spontaneity. Soldiers on both sides celebrated Christmas with a moment of peace, singing, soccer, and gift-exchanges. Most people familiar with the story of the Christmas Truce believe the cease-fire began on 24 December 1914 and lasted throughout the entirety of Christmas Day, however in some places it extended beyond the assumed timeline, starting early and ending several days later. ${ }^{16}$

In the trenches just south of Ypres, the informal truce began a week earlier. Germans soldiers tiptoed across the lines and delivered a chocolate cake with a note in English into the 
enemy trenches to invite them to cease-fire and enjoy a concert featuring singing German soldiers to celebrate their commander's birthday. The British accepted and shared a gift of tobacco. Although they yelled words of rivalry after the concert, there were no casualties that night during the first precursor to the Christmas Truce. ${ }^{17}$

On Christmas Eve along the western front between Ypres and Lille, the Germans lit small candles affixed to their Christmas trees with miniature clamps. Across no man's land, the British soldiers peaked out to see the sparkling wonder. The Germans sent a small group of men to propose a Christmas Truce and although regulations on both sides strictly forbade this behavior, the troops agreed as their young officers looked the other way. That evening similar events happened all along the Western Front. The weather became quite cold and froze the mud that had plagued the soldiers for months, making movement easier and, suddenly, the morale increased and both sides began to experience hope. ${ }^{18}$

Elsewhere on the Western Front, near the town of St. Yvon, a lieutenant documented the oddity of the silence. That silence did not last for long as he heard British troops down the way break into song: not Christmas songs, but soldier’s songs. The nearby Germans light-heartedly reviewed the singing and answered with their own songs accompanied by accordions. ${ }^{19}$ In yet another location, enemy soldiers engaged in peaceful conversation. When a British soldier mentioned there was only one more hour until Christmas, the Germans responded by asserting it was already Christmas in Berlin. At that moment, one German with a baritone voice, sang the universally recognized "Stille Nacht, heilige Nacht."20

Music was extremely prevalent throughout the Christmas Truce. “Lo, How a Rose E’er Blooming”, Handel’s “Largo” from Xerxes, and “Adeste Fidelis” were all sung or played on harmonicas, bagpipes, and violin. These traditional Christmas songs were common to many of 
the cultures represented on the Western Front. Crown Prince Wilhelm of Prussia visited the trenches with a famous opera singer to entertain his soldiers. The enemy reportedly cheered and clapped until an encore was performed, as they enjoyed the music as much as the target audience. $^{21}$

Up and down the trenches, German soldiers displayed signs in broken English on Christmas morning. The most common message shared was "YOU NO FIGHT, WE NO FIGHT.” Soldiers were coming together to share their Christmas bounty. "Yuletide carols initiated a tentative courtship that further developed through physical contact and ultimate the sharing of the soldier's most valued commodities- food and tobacco and such souvenirs as uniform buttons and insignia.”22 The ease with which the Christmas Truce began surprised soldiers on both sides, as many British soldiers believed their German counterparts to be bestial and the Germans believed British and French to be soulless and materialistic. ${ }^{23}$

The soldiers exchanged more gifts, made new friends, and played makeshift soccer between the trenches. One thing common to almost every exchange was music. Music initiated relations, captured attention and demonstrated, from a safe position, that your side was human. The proven humanity in that initial contact started a dialogue from which to build relationships. In some cases, the music was common to both sides, as in the example of "Silent Night" and in others it was regimental songs of pride, but the songs themselves are less important than the effects they had on the minds of the soldiers. Their enemies were human and as they explored further, more and more evidence supported their initial, music-inspired opinions. Perhaps the soldiers on both sides were more alike than any had previously believed.

Despite the soldier's newfound familiarity, World War I did continue with fighting in the trenches of the Western Front for three more years. Some enemy soldiers, now friends, had 
proposed more soccer games and similar truce situations for New Year's Day and perhaps other days in the future. Many units parted with their new friends amicably and set up a system to return to hostilities with the signal of the flare in the next few hours. ${ }^{24}$ Captain Armes of the $1^{\text {st }}$ North Staffordshire Regiment allowed his men to continue contact "until dusk, when we go in again and have songs until 9 P.M.” he wondered when hostilities would truly restart as he knew the men had made arrangements to simply shoot into the air instead of attacking each other. ${ }^{25}$

Leadership on both sides became aware of the informal truce late on Christmas and the next day they started efforts to terminate it. The Generals' jobs were to further their nation's political goals through winning in warfare. The leadership had methods to end this unsanctioned peace. A British General went to the front trenches in one area to warn of an upcoming attack planned by the Germans, he was however, directed to units that had not partaken in the truce. ${ }^{26}$ Officers threatened prosecution for fraternization on both sides to get the troops back to fighting. Leadership forbade the soldiers from having the tokens they had exchanged with the enemy. In some places, schedulers accelerated reserve rotation to change out the units on the front lines with the reserves who had no ties with the enemy to hasten the finale of the Christmas Truce.

The Truce ended in each area differently. The most effective method to end hostilities was reserve rotation, but others witnessed spontaneous violence and responded in accordance with their training. As Christmas of 1915 approached, leadership preemptively spread the word of harsh punishments for fraternization. There were several courts-martial held for minor infractions. Leadership publicized the incidents to ensure the soldiers understood the activities of the previous year would not be tolerated. Despite these measures, there were a few short-lived truces again, but the scope and scale did not compare to 1914. This was partially due to the 
success of pre-emptive measures and partially due to continued war fatigue. Soldiers did not want to be friends with their enemies again.

"The event appears in retrospect somehow unreal, incredible in its intensity and extent, seemingly impossible to have happened without consequences for the outcome of the war."27 There was a clear motivation for peace demonstrated in the acts of the soldiers. The fielded troops were desolate and exhausted. A shared cultural event with the enemy, initiated in many cases by shared music, brought purpose to their existence. Many had lost all combat motivation following this incident. Yet, one knows that the war continued and this event faded off into the past as the new friends resumed hostilities. The individual motivation of the soldiers was unable to surmount the obstacles of the situation. They had no choice but to fight.

Music was important throughout WWI for soldiers involved on all sides. Americans rallied around the song "Over There.” This song was to a marching beat and sang the praises of brave young American soldiers. There were also those who rallied around the popular songs from the Civil War including "Dixie” and other southern battle hymns. It was not long before songs like "Dixie Doodle" became popular; showing integrity between the North and the South was something around which to rally. ${ }^{28}$ "The soldier's songs and the rag-tag entertainment [...] became an emblematic antidote to the deafening and unremitting roar of the battlefield. ${ }^{29}$

American soldiers repeatedly shared their feelings regarding the occasional celebration of music on the battlefield. The sentiments were shared not only by soldiers but also by others in witness of the events. The Saturday Evening Post in August 1918 featured an article written by a journalist, often noted for his sarcasm, which beautifully articulates the power that music had on the front lines. Earlier that day two dozen patrolmen had been killed in a battle and the group of journalists witnessed the immediate aftermath. 
We stood with the regimental staff on the terraced lawn of the chief house in a half-deserted town five miles back from the trenches, and down below us in the main street the band played plantation airs and hundreds of negro soldiers joined in an sang the words...

And when the band got to Way Down Upon the Suwannee River I wanted to cry, and when the drum major, who likewise had a splendid baritone voice, sang, as an interpolated number, Joan of Arc, first in English and then in excellent French, the villagers openly cried. ${ }^{30}$

The peaceful interludes in war, initiated by music, were powerful events. It is evident that music has a strong effect on combat motivation and it is essential to explore and understand how that mechanism works. First, one must explore human motivation at its core and then move on to greater depth in exploring the factors that inspire and drive soldiers in combat. Once the basics of combat motivation are understood, it is important to discuss psychological impact of music on the human brain and how its integration into the combat environment can drive the success and motivation of the fielded forces.

Abraham Maslow is famous for developing his hierarchy of needs, depicted as a pyramid in the 1940s; he then expounded on his work with an exploration of human motivations with respect to these needs in the 1950s. It is very insightful in understanding the motivations of a soldier. He asserts that "motivation is constant, never ending, fluctuating and complex" and he goes on to describe the drivers as "an almost universal characteristic" of all beings. ${ }^{31}$ The physiological needs are the most basic need of the human. When those needs are met, safety becomes the next priority. In combat, physiological, and safety needs are not often met. They will be the driving force for most soldiers as long as they are not realized. Once those needs are met, love and belongingness are the next priority. Much of the love and belonging needs are met in combat by primary group support. The support and cohesiveness of a primary combat group is widely recognized as an essential element of combat motivation. 
The first three levels of Maslow's pyramid are of primary significance when exploring human motivation in the combat soldier, but it is a worthy discussion to continue to explore the remaining human needs. Esteem, composed of achievement, competence, and confidence as well as recognition, attention, importance, and appreciation make up the next set of basic needs. Then after all others are met, humans then need to realize self-actualization. Self-actualization is simply explained as the situation when a person is able to do or be what they feel they should. An artist reaches self-actualization when he or she is allowed to actively create art.

It seems as if based on these needs and motivation principles, it would be impossible to motivate a soldier to risk his most basic physiological need to life, in a combat situation. Maslow goes onto to describe that not all people value the needs in the order he has presented them and exceptions exist. He lists seven exceptions to his hierarchy with the final one being the key to combat motivation. "Perhaps more important that all these exceptions are the ones that involve ideals, high social standards, high values, and the like. With such values people become martyrs: they will give up everything for the sake of a particular ideal, or value.”32 Herein lies the key. If one can call on high ideals in the soldier, one can motivate him or her to risk their lives on the battlefield.

When combat motivation is explored as its own topic, several primary motivational factors standout: primary group cohesion, unit esprit and history, socialization, training, discipline, leadership, rewards and recognition, and personal beliefs, values and commitment. ${ }^{33}$ While all deserve brief mention at this juncture, one will find that the latter is the most pertinent when it comes to the possible combat motivation effects of music. It is also interesting to note how each of these needs can be associated with the basic human needs as presented by Maslow. The best way to view combat motivation is as "a continuum, with a dedicated and aggressive 
soldier at one end, potential defectors at the other, and the remainder (perhaps a majority) somewhere between, no single motivator is likely to appeal to all groups equally for any length of time. ${ }^{34}$

Primary group cohesion has been credited with much of the motivational force pushing soldiers to risk their lives in combat. It is clearly an important driver for human interaction on the battlefield, however it is now widely established that "Loyalty to the primary group and the pressures that loyalty exerts on the individual are important elements in combat willingness but are not sufficient explanation of why men fight."35 The bonds formed in the primary groups provide for the basic human need of love and belongingness. Many argue the primary basis for solidarity lie in the recognition of shared mutual risk among the soldiers. ${ }^{36}$ This is clearly a very important piece of understanding combat motivation.

Unit esprit, socialization, and training are three additional motivating factors. "Unit esprit refers to the soldier’s identification with organizational levels above his primary group. ${ }^{\text {37 }}$ The United States has many units with long histories of battle successes although motivational effects of unit esprit are reported to be more influential in British and Canadian militaries. ${ }^{38}$ This history of victory and modern day esprit motivates soldiers to carry on the fight with more determination than they otherwise would. Socialization refers to the effect of the everyday interactions on new arrivals to a unit. Soldiers arriving with little or no combat experience adopt the culture in which they find themselves. Training has a similar effect in that basic training breaks down a soldier and recreates them in the image the military desires. The success of this process varies with many factors including popular support for military, conscripted forces versus all-volunteer military and training techniques. Such training instills a sense of confidence 
in capability. Together these factors all work toward love and belongingness as well as esteem to help motivate the soldier to serve. ${ }^{39}$

Discipline is another major factor in combat motivation. Discipline is a basic tenet of military life and it is present in most, if not all, national militaries throughout history. Of interest to note, the Confederate army initially did not have a clear regulatory system for discipline. Men of the South considered themselves gentlemen and they deemed they had no need for regulations on punishments. In late 1865, regulations began to be created and enforced. ${ }^{40}$ General discipline and good order played a large part in motivating soldiers to continue their duty, but of special interest when discussing motivation is the regulations and history surrounding punishment of deserters. During the Civil War, officials estimated that the Union suffered roughly 201,000 deserters and the Confederacy suffered approximately 100,000. That set the rate of desertion of enlisted troops at 32.6 percent. Combat refusals were significantly less by WWI with one American and 263 British troops executed for desertion. ${ }^{41}$ When combat troops are aware that fellow soldiers are being tried and executed it has quite a significant coercive effect. A person's physiological and safety needs would drive compliance with regulation in this situation according to Maslow's hierarchy. This type of discipline is an extremely effective deterrent, however, in today's climate, execution of deserters with a trial would scarcely be accepted publicly, making this method of motivation unusable in today's standard military environment.

Quality leadership at the lowest levels has traditionally led to strongly motivated combat troops. Soldiers react positively to leaders would go through the same conditions and hardships shared by the troops while leading operations and taking care of the unit. That respect can have positive or negative motivational effects depending on the traits of the leader. Good leaders inspire dedicated and motivated soldiers. Another option for good leaders is to provide 
recognition to their troops and to provide rewards whenever the situation allows. Rewards offer great payback in terms of troop morale and motivation.

Personal beliefs, values and commitment are vitally important to combat motivation for individuals. Most of the other criteria discussed addressees the entire unit, where each person's ideology is not considered. Within the primary group, certain vibrant personality types can steer the attitude of the whole group. Additionally each follower will be susceptible to every stimulus in combat differently. Each of these factors affects the group through individuals, greatly influencing the combat effectiveness of units. Many enlist with strong roots of patriotism or belief in the cause. Many do so out of family values and the need to serve. In numerous wars, conscripts start their military careers with little interest in combat. These factors together shape an individual's susceptibility to leadership and action in battle. Preconceptions of a combat environment often adapt and change with experience. Calling on beliefs, patriotism and values can be done through music.

Thoughts of home sustain many military members as they endure unbearable hardships. Home represented a tangible link the grandiose ideals for which Americans fight. Freedom and democracy are nice ideas, but to an individual suffering in difficult circumstance, home came to be the idea to rally oneself around. Letters from the home front were essential to combatants in all conflicts where mail was available. "Soldiers were notorious daydreamers."42 When they could not physically escape a situation, many would mentally return to the ideal home they left. Many thought of times they experienced and others planned for a life after their war. When news of hardships back home reached soldiers, they had a variety of reactions. Some felt angry to be told about problems that were minor in comparison to the harrowing and miserable conditions experienced in front line combat. Others felt helpless to aid their loved ones in hard 
times. "Confederate soldiers endured great hardships, but more depressing than their own suffering was the knowledge that their families at home also faced severe deprivation."43 Many soldiers grew disproportionately concerned when mail was not regular from home. Others who received "Dear John" letters were devastated. These types of reactions were influential on the combat motivation of individuals and therefore on the units in which they fight.

Soldiers’ obsessions with home allow music exposure to combatants in battle to be effective motivation tools. Songs arouse feeling surrounding these intensely personal and driving thoughts of home. Many nostalgic songs transport a person to another time and place and allow a moment of reflection. In some cases, the motivation to fight temporarily decreases, but in the long run it can strengthen resolve of soldiers to their original ideals. Patriotic music can stir feelings that drove a soldier to the fight initially. Music that is fun or light can temporarily lighten combat stress. The effects of music on the individual can be varied and strong across a large array of situations.

In the same way it is important to study the science and psychology behind combat motivation to further this discussion, one must explore the same scientific connection to music, mood, and action. Considered in a context vacuum, psychologists assert "Music causes us to experience moods, leading us to hear the music as sad or happy, or perhaps even anxious or patriotic."44 This mood induction is a powerful trait in music. Moods are technically described as “objectless affective states.” When discussing their effects one must consider "They are not about or directed toward anything in particular. Instead, they pervade our thoughts and behavior, coloring our perception and interaction in sometimes subtle, but global ways." ${ }^{45}$ A person’s mood can create an environment where other inputs and stimuli are perceived differently than if that input occurred coincident with a different mood of the subject. Furthermore, music is 
particularly effective in drawing a specific mood from a subject in that it can do so "covertly" without the subject's knowledge or consent and “it does so without priming any particular thoughts or concepts."46 Once it is established music can affect mood, the next logical question is how moods affect decisions and actions.

Psychologists have discovered that mood influences decisions through "introspection, perception, anticipation, and choice of cognitive strategy."47 In exploring the linkage between music's mood inducing power and the power mood has over decisions, it is clear to see that music provides a mental framework in which decision are made. "Mood seems to work as context in the sense that people perceive two identical logical structures differently depending on their mood.”48 It is as if the mood filters the incoming information to create the structure that the mind is prepared for. It is more than pure decisions that are affected by mood, "There is a large experimental literature in psychology that has documented the effects of mood on memory, judgments or self and others, risk perception, and choice of cognitive strategy."49 Clearly, music can have a dramatic effect psychologically on those who listen.

The music in the experimentation above was without lyric or direct mental context. Meaning when you combine the pure music with an image or environment, it becomes even more powerful. Experts argue "Both psychologists and political scientists recently have claimed that emotions play a fundamental role in reasoning and are as likely to enhance rationality as to subvert it."50 The situation in which it is heard or shared defines the experience. Nostalgic music calls on positive thoughts from a person's past and evokes emotion and mood in multiple ways. If the pure music form is matched to the content of the lyrics and then exposed to individuals who can give a song further context, a powerful set of emotions can be drawn upon. 
It is possible to create motivation, positive or negative, with the right combination of music and context.

Following WWI, many started to recognize the strong effects music could have on the combat motivation of thousands of soldiers. The next logical question became, "How can this information can be used in the future?” Can it be used against our forces? Can we use music to motivate our own soldiers or demoralize the enemy? These questions came into play as World War II propaganda attempted to capture the power of music to frame the perfect message in order to affect individual soldier's motivations.

During the interwar period, radio broadcasting became prominent and readily available around the world. By 1941, Americans were listing to an average of 4.5 hours of radio per day. ${ }^{51}$ The Nazi party sought to take advantage of this technology and pursue informational warfare by priming the interior of Germany as well as their European neighbors for Nazi ideals and eventual territorial dominance. In 1933, Hitler created a Propaganda Ministry and chose the talented and motivated Joseph Goebbels as its leader. Goebbels was influenced by two guiding principles from Hitler’s famous book, Mein Kampf: “you must appeal to the lowest common mentality” and “if your appeal was properly made you could sell anybody on anything."52

Goebbels tapped into existing technological resources using medium and long wave radio stations within Europe. He also acquired a series of short wave transmission stations that he could use to send messages even further. He continued adding transmitters and developing programming for internal and foreign use. By 1943, the Germans were broadcasting more than 200 international programs, in greater than 30 languages all over the world including countries as distant as India and Argentina. ${ }^{53}$ 
As the war progressed, occasionally Allied or resistance fighters would gain access to some form of broadcasting capability and create a "freedom station.” These freedom stations could not last long for fear of being found by the Axis, but they were a way of promoting Allied ideologies. It was not long before Germany understood the impact these stations had on their enemies. They began to mimic freedom stations, but with the Nazi ideology subtly entrenched in the commentary. They broadcast misinformation and demoralizing lies creating confusion and mistrust among their enemy's ranks. The Germans had a series of broadcasts aimed at England attempting to exploit the social divisions among the working classes and create tensions. Both authentic and fake freedom stations continued to exist throughout the war.

Goebbels recruited native speakers to broadcast the Nazi message to their home countries. This was a particularly effective way to get the message across, because even if the words were clearly "propaganda," it was intriguing to try to identify the speaker. People would listen out of curiosity to find out what traitorous message was on the airwaves. Of course, much of the discussion and messaging was interspersed with music to make the broadcasts more appealing. ${ }^{54}$

Germany used much of their foreign broadcasting to target political ideas on the home front, but they also beamed their messages effectively during battlefield operations and to encamped soldiers from all Allied cultures. During the invasion of France, Germany had three stated aims in using radio propaganda "first, the political theme, aimed at dividing France from England; second, the military theme, aimed at confusing the troops; and third, the morale theme, aimed at breaking down resistance both at the front and behind the lines." ${ }^{, 55}$ It is important to note that the second and third stated goals were directed toward combat troops. The Germans targeted enemy soldiers, not only in France, but wherever they could find listeners. 
The book, Axis on the Air, captures an excellent example of a propaganda broadcast aimed at Americans in North Africa.

It is spring, 1943. An American soldier at a camp somewhere behind the lines in North Africa idly turns the dial of a portable radio. He is tired and a little homesick. Suddenly he perks up, for out of the loudspeaker come the strains of "Home, Sweet Home." He listens and nudges his buddy to see if he recognizes the music. Together they listen until the sound is ended. They wait, wondering where it has come from.

Then a soft voice is heard, a woman's voice, soothing and ingratiating. She is speaking English.

"Well, boys," she says familiarly, "my poor American boys, things don’t look so good for you, do they? Here you are, thousands of miles from home, in a foreign land that means nothing to you. While your home, sweet home is in danger. And what are you fighting for? For the English, who mock you and school at you at every opportunity. Don't do it boys! Don't get yourselves killed or maimed for life for the English, or for the Bolsheviks!" 56

The broadcast attacks the morale of the American troops. It is interesting to note the distinctly American flavor to the broadcast, even so far as calling on the long beloved song "Home, Sweet Home” to bring the soldier's mind not only to his home, but also to his heritage. The native speaker uses a combination of music and a soft voice to capture their attentions, even if only for a few moments, and spread their message. This is an enemy of America, attempting to use music in a way that has been demonstrated in the past, to reduce a soldier's will to fight.

Similar broadcasts, though many would argue less nuanced, aired in the Pacific theater. The Japanese had clearly stated goals for their broadcasts for both foreigners and their own citizens. Radio Tokyo wanted to frighten Americans, thereby restricting their ambitions only to protect their homeland, intimidate American flyers to prevent air attacks on mainland Japan, make the world believe the war guilt belonged to the Americans, and destroy morale through long range English language broadcasts to the continental United States. At home, they hoped to 
incite hatred based on nationality by influencing their population to hate the white race and to convince the Japanese people of their invincibility. ${ }^{57}$

Radio Tokyo broadcast many songs along with their ideological message, however, in an interesting self-inflicted limitation; the Japanese would not air certain types of music. They deemed over 1,000 American and British songs "inappropriate to the times." Many of these songs were of "jazz" origin as deemed by the Japanese. They did air music that they considered more in line with their own sentiments including "Home, Sweet Home," “Auld Lang Syne,” and "The Last Rose of Summer." ${ }^{\text {58 }}$ By placing these types of limitations on propaganda broadcasts, they were never going to reach the American soldiers in their audience. The Japanese lacked the full commitment to use the enemy culture in the most persuasive way.

American airmen stationed in the Pacific voiced their opinion of Radio Tokyo in a letter through the International Red Cross addressed to Prime Minister General Hideki Tojo. In the letter, they explain that they are entertained by the Japanese version of the truth and that is "throwing the world into a convulsion of laughter." The letter goes on to explain they are "entitled to better service" in reference to the music selection. They remark on the Radio Tokyo theme song "My Bonnie Lies over the Ocean" and that it is played on an out of tune piano. The airmen recommend the announcers learn better English. They request Radio Tokyo invest in a better library of American music that is available at any good music store. The letter then acknowledge that there is likely no time for the changes they request, as Americans will soon occupy the station on their soil and will broadcast “The Star Spangled Banner” and they close with “So Long, Tojo! We'll be bombing you!"59 The reaction from the fielded fighting forces indicates that propaganda in the Pacific was less effective than in the European theater. The 
Japanese were less able and less willing to understand the minds of their enemy in the realm of music and messaging.

Axis powers were not the only ones broadcasting to foreigners during WWII. Voice of America had foreign stations in place attempting to meet two broad aims: first to "weaken the Axis morale” and secondly to" build the morale of the conquered people awaiting liberation by the Allied armies. ${ }^{\prime 60}$ They presented accurate news from the Allied perspective. There was a clear bias, but they aimed not to broadcast lies. The BBC broadcast in 45 languages with 107 news transmissions daily and 22 supplementary weekly news updates. They also employed morale building personalities specific to their target broadcast country including everyone from royalty to writers to comedians. The efforts of the Allies were evident; they wanted to gain trust and build ties for after the war. Their results were less persuasion based than their Axis counterparts. ${ }^{61}$

Domestically during the opening years of the war, an effort began to create the perfect martial war song. The Office of War Information (OWI) encouraged songwriters to create the ideal piece to rally people on the home front and to inspire the fielded soldiers. The song "Over There," popular during WWI, was the model they wanted to follow; yet by the end of the WWII their efforts were unsuccessful in creating the perfect song. The OWI helped in the creation of several moderately popular war songs, but none with the patriotism and power for which they had hoped. The OWI went so far as to create criteria that songs must fit to be featured in certain venues and promoted with the government's backing. The problem was that the tastes of the American people had changed over time.

“Publishers stayed away from war songs, claiming the public's interest was in romantic or novelty songs, not battle hymns.”62 The OWI had very specific ideas about what a war song 
should be and it was not necessarily aligned with the profitable marketplace. Perhaps this friction led to the failure to produce the wartime rally song that the US government sought. The OWI maintained that sentimental songs and those looking forward to the end of hostilities were unsuitable for rallying popular support. ${ }^{63}$ Songs should not underestimate the strength of the enemy nor create humor around them. Songs should play to the strengths of our UN partners. Music may not encourage disunity within the US. Songs must avoid overstatements and superlatives, including stating something was the "best" or the "only" way. They were encouraged not to glorify the armed services too much as war must be thought of as a negative thing. The horrific side of war cannot be portrayed. Boasting about US past wartime successes was looked upon as diminishing our allies so that was also discouraged. ${ }^{64}$ The restrictions limited artists and fought the popular trends of the day. "During WWII civilians and soldiers put their own blueprints on war songs, which were far different from those Americans sang in previous wars.

Calling on various sources including surveys conducted of servicemen by Billboard, it is clear the soldiers did not want to listen to patriotic war songs. The deployed troops longed for the war to be over and to return home. They better associated with the concrete idea of home than with the more vague notions of freedom and democracy. Music that reminded them of their homes, families and girlfriends fueled their spirit and allowed them strength to fight. ${ }^{66}$ They also found fortitude in humorous songs poking fun at the enemy. "Der Fuehrer's Face” is a great example of a novelty song that blatantly ridicules Hitler, and the United States Armed Forces loved it, along with the rest of the country. ${ }^{67}$ Soldiers no longer were drawn to the marching beat of a song as marching was far less prominent in modern mechanized warfare, again drawing them back to nostalgic and novelty songs with which they could sing along. ${ }^{68}$ 
American soldiers longed for the swing and big band music that had grown in popularity in the years leading up to WWII. Youth in the US had flocked to this style of dance music as it broke racial and societal barriers. The older generations believed swing music to be an abomination and the OWI echoed this concept by blaming the Big Bands for promoting music contrary to the common decency. ${ }^{69}$ But as the younger generation went to war, their swing music went with them. Glenn Miller was a successful musician who felt a patriotic duty to join the military during WWII. As a 38 year old, he asked to be in charge of a band and his request was granted. He founded the Army Air Corps Band and successfully entertained and motivated the troops by performing and creating the style of music that the young soldiers identified with home. Miller served for only a short time as his plane went missing while crossing the English Channel en route to a military musical performance, but his legacy in military music is still strong today.

WWII saw governments understanding the motivating power of music and attempting to harness it to influence the outcome of the war. Through propaganda, broadcasts interspersed with national popular music all the governments involved played some part in trying to affect the morale of the population back home and the fielded forces. To ensure the best chance of accomplishing one's goals, it is essential to understand the music and the culture as a whole. To influence a population of fielded forces effectively, one must work within the context of what the listeners want to hear. This key point was lost on most governments during the WWII timeframe with the notable exception of Nazi Germany. They were successfully able to provide programing that drew in their target audience. It is hard to quantify how much impact the Nazis had with their broadcasts and it is equally hard to know if the OWI accomplished anything 
lasting through their efforts. However, the broadcasting events from WWII display a marked turn in the way governments looked at the medium of music and its persuasive power.

Popular culture had changed by the time the US entered Vietnam. The government recognized the potential power in using music to motivate troops in this conflict. The USO sponsored tours of musicians and the military created the Armed Forces Vietnam Network (AFVN) airing modern music of the day. Many soldiers considered the USO shows and performers relics from prior conflicts. The soldiers reflected a cross section of American youth and the programming did not impress them. Additionally, many front line soldiers were vaguely aware of USO shows but were never offered an opportunity to partake. One soldier made reference to the only special entertainment opportunities available to his unit was a base stand down with an Asian strip show or an Australian band. The USO shows were not an effective use of music as motivation in the Vietnam conflict. ${ }^{70}$

AFVN radio, however, united soldiers through music. The most well known story from this era is portrayed in the fictional movie Good Morning, Vietnam. Adrian Cronauer, an actual Air Force radio announcer in Vietnam, wrote this movie and although it is fictional, it has a basis in reality on his own experiences. Cronauer chose to spend one year in Vietnam on the air and he brought with him enthusiasm and a modern approach to radio. He pushed the limitations of military broadcasting, but he did not push hard enough to lose his position. He did his best to play the music that soldiers wanted to hear. ${ }^{71}$ Moreover, whether through military radio, civilian radio or recorded genres coming from home, the soldiers were able to listen to the music of their choosing. In this conflict, they wanted to hear the same music they had been hearing at home. ${ }^{72}$ Veterans of the Vietnam conflict describe the constant presence of music throughout their service. They were able to consume music of all kinds. Of particular popularity was hard rock, 
specifically the Rolling Stones. There was a culture of drugs, war itself was violent, and many young soldiers identified with this type of music. Soldiers celebrated the occasional "feel-good" song of the era as well as California songs and Motown. Much of what an individual soldier preferred was the same that he had enjoyed back home. ${ }^{73}$ Songs that embodied the completion of a soldier's tour were particularly celebrated. The Boxtops' "Gimme a Ticket for an Airplane” and the Animals' "We Gotta Get out of This Place" were adopted as anthems of the celebrated return home. ${ }^{74}$

In the United States, the musical landscape of the country was unlike that of any previous war. "Composers no longer wrote compositions to support war [...] they openly protested the war and expressed anti-government sentiments directly and to a degree unprecedented in history."75 There was a resurgence of folk music and in that genre was a strong anti-war movement. "The Universal Soldier” and "Where Have All the Flowers Gone” are both popular examples of the types of folk music prevalent near the beginning period of the war. There was a partially successful attempt in the country music sector to counter the anti-war songs with some supportive music. The chosen message was in plight-of-the-soldier style songs. In the grand popular music market of the times, both genres were in the minority, but the anti-war music was significantly more widespread. ${ }^{76}$

The armed forces in Vietnam listened to the popular music of the day, and although airplay of anti-war music was rare, there was very little music supporting their efforts. This marked a departure from all past conflicts involving American troops. In the words of a Vietnam veteran, "In the particular case of the music of the Nam, with the exception of the occasional country song, one remains struck by the absence of a contemporary musical tradition expressing public support for the war or its combatants." ${ }^{, 77}$ A classic debate on arts in civilization is 
illustrated when considering whether music imitates the culture in which it is created versus music shaping the culture into which it is introduced. To some degree, both are true and it is clear that the support and motivation found in music in previous American wars was clearly nonexistent in the Vietnam War.

Music was not a successful motivation tool in Vietnam. There were few appropriate songs to stimulate the ideals of a soldier. US involvement in this conflict was debated and many soldiers did not believe in the Vietnam War in general, hence one could not call on their internalized principles to create motivation. Music was a successful boost to morale, in that soldiers could entertain themselves listening to the music of their choice, but there was no marked success in motivating combat effectiveness.

So what does the link between music and combat motivation mean for today's conflicts and those of the future ${ }^{78}$ The technological landscape has changed dramatically from the days of Vietnam. Today, each soldier can carry their own preferred library of music including thousands of songs in their pocket. Are broadcasts still relevant? For that matter, are military bands still relevant? Can our adversaries use music to affect our armed forces and can we use music to influence their soldiers?

Broadcasts are relevant for many soldiers because they contain current information and news as well as a shared experience with other soldiers to discuss. Music as a shared experience is often more enjoyable then the isolated experience of a singular person with an iPod. With the assumption that some broadcast music will remain present in combat for at least the near future, it is clear that the United States must work to understand the effects. The lessons of the past must be learned, communicated, and explored for possible kinks in our own psychological armor as well as that of our enemies. 
The shared music events between enemy forces in the American Civil War and WWI demonstrate the powerful influence music can have on combat motivation in fielded forces. Those historical examples paired with the study of motivation, combat and music's ability to affect mood highlight the importance of understanding music as a combat motivator. As the world became aware of the power of music and the technology was available to exploit that power, propaganda interspersed with the proper choice of songs was exercised in attempts to manipulate combat motivation with varying degrees of success during WWII. The United States ineffectually attempted to use music to motivate combat soldiers serving in Vietnam. It is critical to understand the elements involved to create the desired effects in future conflict and to avoid becoming victim to the influences of music used against US Armed Forces.

Music has a clear and undeniable ability to affect motivation and morale in combat soldiers. The degree to which it can influence an individual depends highly on the context and situation in which that person exists. A deeper understanding of music's ability to shape motivation is critical to defending American fielded forces from the influence of any future adversary. With greater understanding of music as a motivational stimulus, it is possible for the United States to enhance combat effectiveness and for that reason; further research should be conducted to better understand the power of music in a combat environment.

\footnotetext{
${ }^{1}$ Ernest L Abe, “'Home, Sweet Home’: A Civil War Soldier’s Favorite Song.” (America’s Civil War, May 1996).

${ }^{2}$ Stanley Weintraub, Silent Night: The Story of the World War I Christmas Truce. (The Free Press: New York. 2001) 121-155.

${ }^{3}$ William R. Trotter, “The Music of War.” Military History Magazine (June 2005).

${ }^{4}$ William R. Trotter, "The Music of War.” Military History Magazine (June 2005).

${ }^{5}$ Alfred M. Williams, "Folk-Songs of the Civil War." (The Journal of American Folk-lore Vol V October 1892.) 267.
} 
6 “Civil War Music History and Songs.”

http://www.americancivilwar.com/Civil_War_Music/civil_war_music.html

7 “Civil War Music History and Songs."

http://www.americancivilwar.com/Civil_War_Music/civil_war_music.html

${ }^{8}$ Ernest L Abe, “'Home, Sweet Home’: A Civil War Soldier’s Favorite Song.” (America’s Civil War, May 1996).

${ }^{9}$ Ernest L Abe, “'Home, Sweet Home’: A Civil War Soldier’s Favorite Song.” (America’s Civil War, May 1996).

${ }^{10}$ Ernest L Abe, “'Home, Sweet Home’: A Civil War Soldier’s Favorite Song.” (America’s Civil War, May 1996).

${ }^{11}$ Ernest L Abe.,“’Home, Sweet Home’: A Civil War Soldier’s Favorite Song.” (America’s Civil War, May 1996).

${ }^{12}$ Ernest L Abe, “'Home, Sweet Home’: A Civil War Soldier’s Favorite Song.” (America’s Civil War, May 1996).

${ }^{13}$ Ernest L Abe, “'Home, Sweet Home’: A Civil War Soldier’s Favorite Song.” (America’s Civil War, May 1996).

${ }^{14}$ The Civil War Preservation Foundation's website, http://www.civilwar.org.

${ }^{15}$ Stanley Weintraub, Silent Night: The Story of the World War I Christmas Truce. (The Free Press: New York. 2001) 8-10. Additional Note: Allied soldiers were from England, France, Belgium and India while German soldiers were Prussian, Westphalian, and Saxon.

16 The Truce was not complete nor was it followed in all locations. There were cases of violence that Christmas Eve and Christmas Day, but they were the exception.

${ }^{17}$ Stanley Weintraub, Silent Night: The Story of the World War I Christmas Truce. (The Free Press: New York. 2001) 12-13.

${ }^{18}$ Stanley Weintraub, Silent Night: The Story of the World War I Christmas Truce. (The Free Press: New York. 2001) 13-15.

${ }^{19}$ Stanley Weintraub, Silent Night: The Story of the World War I Christmas Truce. (The Free Press: New York. 2001) 16-18.

${ }^{20}$ Stanley Weintraub, Silent Night: The Story of the World War I Christmas Truce. (The Free Press: New York. 2001) 22.

${ }^{21}$ Glenn Watkins, Proof through the Night: Music and the Great War. (Los Angelos, CA:

University of California Press, 2003) 66.

${ }^{22}$ Stanley Weintraub, Silent Night: The Story of the World War I Christmas Truce. (The Free Press: New York. 2001) 27.

${ }^{23}$ Stanley Weintraub, Silent Night: The Story of the World War I Christmas Truce. (The Free Press: New York. 2001) 24.

${ }^{24}$ Stanley Weintraub, Silent Night: The Story of the World War I Christmas Truce. (The Free Press: New York. 2001) 133.

${ }^{25}$ Stanley Weintraub, Silent Night: The Story of the World War I Christmas Truce. (The Free Press: New York. 2001) 134.

${ }^{26}$ Stanley Weintraub, Silent Night: The Story of the World War I Christmas Truce. (The Free Press: New York. 2001) 149.

${ }^{27}$ Stanley Weintraub. Silent Night: The Story of the World War I Christmas Truce. (The Free Press: New York. 2001) xvii. 
${ }^{28}$ Glenn Watkins, Proof through the Night: Music and the Great War. (Los Angelos, CA: University of California Press, 2003) 283.

${ }^{29}$ Glenn Watkins, Proof through the Night: Music and the Great War. (Los Angelos, CA: University of California Press, 2003) 73.

${ }^{30}$ Glenn Watkins, Proof through the Night: Music and the Great War. (Los Angelos, CA: University of California Press, 2003) 316.

${ }^{31}$ Abraham H. Maslow, Motivation and Personality. (New York: Harper \& Row Publishers, 1954) 24.

${ }^{32}$ Abraham H. Maslow, Motivation and Personality. (New York: Harper \& Row Publishers, 1954) 53.

${ }^{33}$ Anthony Kellett, Combat Motivation: The Behavior of Soldiers in Battle. (Boston: Kluwer Nijhoff Publishing, 1982) ix.

${ }^{34}$ Anthony Kellett, Combat Motivation: The Behavior of Soldiers in Battle. (Boston: Kluwer Nijhoff Publishing, 1982) 334.

${ }^{35}$ Anthony Kellett, Combat Motivation: The Behavior of Soldiers in Battle. (Boston: Kluwer Nijhoff Publishing, 1982) 319.

${ }^{36}$ Anthony Kellett, Combat Motivation: The Behavior of Soldiers in Battle. (Boston: Kluwer Nijhoff Publishing, 1982) 102.

${ }^{37}$ Peter S. Kindsvatter, American Soldiers: Ground Combat in the World Wars, Korea and Vietnam. (Lawrence, Kansas: University Press of Kansas, 2003) 134.

${ }^{38}$ Anthony Kellett, Combat Motivation: The Behavior of Soldiers in Battle. (Boston: Kluwer Nijhoff Publishing. 1982) 46-59.

39 Anthony Kellett, Combat Motivation: The Behavior of Soldiers in Battle. (Boston: Kluwer Nijhoff Publishing, 1982) 67-81.

40 Anthony Kellett, Combat Motivation: The Behavior of Soldiers in Battle. (Boston: Kluwer Nijhoff Publishing, 1982) 135.

${ }^{41}$ Anthony Kellett, Combat Motivation: The Behavior of Soldiers in Battle. (Boston: Kluwer Nijhoff Publishing, 1982) 109-110.

42 Peter S. Kindsvatter, American Soldiers: Ground Combat in the World Wars, Korea and Vietnam. (Lawrence, Kansas: University Press of Kansas, 2003) xxi.

${ }^{43}$ Anthony Kellett, Combat Motivation: The Behavior of Soldiers in Battle. (Boston: Kluwer Nijhoff Publishing, 1982) 17.

${ }^{44}$ Laura Sizer, "Moods in the Music and the Man: A Response to Kivy and Carroll.” The Journal of Aesthetics and Art Criticism Vol. 65, No. 3, (June, 2007) 308.

${ }^{45}$ Laura Sizer, "Moods in the Music and the Man: A Response to Kivy and Carroll." The Journal of Aesthetics and Art Criticism Vol. 65, No. 3, (June, 2007) 308.

${ }^{46}$ Laura Sizer, "Moods in the Music and the Man: A Response to Kivy and Carroll." The Journal of Aesthetics and Art Criticism Vol. 65, No. 3, (June, 2007) 308.

${ }^{47}$ Monica Capra, "Mood-Driven Behavior in Strategic Interactions." The American Economic Review, Vol. 94, No. 2, Papers and Proceedings of the One Hundred Sixteenth Annual Meeting of the American Economic Association. (May, 2004) 367. 
${ }^{48}$ Monica Capra, "Mood-Driven Behavior in Strategic Interactions." The American Economic Review, Vol. 94, No. 2, Papers and Proceedings of the One Hundred Sixteenth Annual Meeting of the American Economic Association. (May, 2004) 367.

${ }^{49}$ Monica Capra, "Mood-Driven Behavior in Strategic Interactions." The American Economic Review, Vol. 94, No. 2, Papers and Proceedings of the One Hundred Sixteenth Annual Meeting of the American Economic Association. (May, 2004) 368.

${ }^{50}$ Ted Brader, "Striking a Responsive Chord: How Political Ads Motivate and Persuade Voters by Appealing to Emotions." American Journal of Political Science, Vol. 49, No. 2, (April 2005) 388.

${ }^{51}$ Kathleen E.R. Smith, God Bless America: Tin Pan Alley Goes to War. (Lexington, KY: University Press of Kentucky, 2003) 9.

${ }^{52}$ Harold Ettlinger, The Axis on the Air. (New York, New York: The Bobbs-Merrill Company, 1943) 21-25.

${ }^{53}$ Harold Ettlinger, The Axis on the Air. (New York, New York: The Bobbs-Merrill Company, 1943) 32-33.

${ }^{54}$ Julian Hale, Radio Power: Propaganda and International Broadcasting. (Philadelphia, PA: Temple University Press, 1975) 140-144.

${ }^{55}$ Harold Ettlinger, The Axis on the Air. (New York, New York: The Bobbs-Merrill Company, 1943) 61-63.

${ }^{56}$ Harold Ettlinger, The Axis on the Air. (New York, New York: The Bobbs-Merrill Company, 1943) 11.

${ }^{57}$ Harold Ettlinger, The Axis on the Air. (New York, New York: The Bobbs-Merrill Company, 1943) 131-132.

${ }^{58}$ Harold Ettlinger, The Axis on the Air. (New York, New York: The Bobbs-Merrill Company, 1943) 269.

${ }^{59}$ Harold Ettlinger, The Axis on the Air. (New York, New York: The Bobbs-Merrill Company, 1943) 146-147.

${ }^{60}$ Harold Ettlinger, The Axis on the Air. (New York, New York: The Bobbs-Merrill Company, 1943) 281.

${ }^{61}$ Harold Ettlinger, The Axis on the Air. (New York, New York: The Bobbs-Merrill Company, 1943) 298.

${ }^{62}$ Kathleen E.R. Smith, God Bless America: Tin Pan Alley Goes to War. (Lexington, KY: University Press of Kentucky, 2003) 5.

${ }^{63}$ Kathleen E.R. Smith, God Bless America: Tin Pan Alley Goes to War. (Lexington, KY: University Press of Kentucky, 2003) 26.

${ }^{64}$ Kathleen E.R. Smith, God Bless America: Tin Pan Alley Goes to War. (Lexington, KY: University Press of Kentucky, 2003) 63-67.

${ }^{65}$ Kathleen E.R. Smith, God Bless America: Tin Pan Alley Goes to War. (Lexington, KY: University Press of Kentucky, 2003) 7.

${ }^{66}$ Kathleen E.R. Smith, God Bless America: Tin Pan Alley Goes to War. (Lexington, KY: University Press of Kentucky, 2003) 86-87.

${ }^{67}$ Kathleen E.R. Smith, God Bless America: Tin Pan Alley Goes to War. (Lexington, KY: University Press of Kentucky, 2003) 69-71. 
${ }^{68}$ Kathleen E.R. Smith, God Bless America: Tin Pan Alley Goes to War. (Lexington, KY: University Press of Kentucky, 2003) 167.

${ }^{69}$ Kathleen E.R. Smith, God Bless America: Tin Pan Alley Goes to War. (Lexington, KY: University Press of Kentucky, 2003) 77-78.

${ }^{70}$ Phillip D. Beidler, Late Thoughts on an Old War. (Athens, Georgia: University of Georgia Press, 2004) 117.

${ }^{71}$ Gordon Zernich, “Adrian Cronauer: Air Force Radio Annoucer in Vietnam.” Vietnam Magazine, Feb 2001, 1-2).

${ }^{72}$ James E. Perone, Songs of the Vietnam Conflict. (Westport Connecticut: Greenwood Press, 2001) 11.

${ }^{73}$ Phillip D. Beidler, Late Thoughts on an Old War. (Athens, Georgia: University of Georgia Press, 2004) 110-114.

${ }^{74}$ Phillip D. Beidler, Late Thoughts on an Old War. (Athens, Georgia: University of Georgia Press, 2004) 119-120.

${ }^{75}$ James E. Perone, Songs of the Vietnam Conflict. (Westport Connecticut: Greenwood Press, 2001) 6.

${ }^{76}$ James E. Perone, Songs of the Vietnam Conflict. (Westport Connecticut: Greenwood Press, 2001) 9-10.

${ }^{77}$ Phillip D. Beidler, Late Thoughts on an Old War. (Athens, Georgia: University of Georgia Press, 2004) 116.

${ }^{78}$ There are new thoughts on using sound in combat, and although different from music, it is of interest to note the current research being done. Sound vibrations can cause physical damage but creation such strong waves is often not worth the equipment required to create it. But new research "explores the rippling shockwaves of these kinds of deployments of sound and their impacts on the way populations feel- not just their individualized, subjective, personal emotions, but more their collective moods of affects." Using the effect of sound on moods and emotions can affect the will of a people to wage conflict. It is an interesting development in using sound for motivation of not only the fighting forces, but also an enemy population at large. 
Table of Selected Civil War Battles by Theatre and Casualty Rates

\begin{tabular}{|c|c|c|c|c|c|}
\hline Battle & Date & $\begin{array}{l}\text { Union } \\
\text { Troops }\end{array}$ & $\begin{array}{c}\text { Confederate } \\
\text { Troops } \\
\end{array}$ & $\begin{array}{c}\text { Union } \\
\text { Casualty \% }\end{array}$ & $\begin{array}{l}\text { Confederate } \\
\text { Casualty \% }\end{array}$ \\
\hline \multicolumn{6}{|c|}{ Eastern Theatre } \\
\hline $\begin{array}{c}\text { Battle of South } \\
\text { Mountain }\end{array}$ & 15 Sep 1862 & 28,000 & 18,000 & $8.3 \%$ & $15 \%$ \\
\hline Battle of Antietam & 17 Sep 1862 & 87,000 & 45,000 & $14.3 \%$ & $23 \%$ \\
\hline $\begin{array}{c}\text { Battle of } \\
\text { Fredericksburg* } \\
\end{array}$ & $\begin{array}{c}11-15 \text { Dec } \\
1862 \\
\end{array}$ & 100,007 & 72,497 & $13.4 \%$ & $6.37 \%$ \\
\hline $\begin{array}{c}\text { Battle of } \\
\text { Chancellorsville }\end{array}$ & 1-6 May 1863 & 97,382 & 57,352 & $17.8 \%$ & $23.5 \%$ \\
\hline $\begin{array}{c}\text { Battle of Brandy } \\
\text { Station } \\
\end{array}$ & 9 June 1863 & 11,000 & 9,500 & $7.9 \%$ & $4.6 \%$ \\
\hline Battle of Gettysburg & 1-3 July 1863 & 93,921 & 71,699 & $24.5 \%$ & $39.1 \%$ \\
\hline $\begin{array}{l}\text { Battle of the } \\
\text { Wilderness }\end{array}$ & 5-7 May 1864 & 101,895 & 61,025 & $18.1 \%$ & $18.7 \%$ \\
\hline $\begin{array}{c}\text { Battle of } \\
\text { Spotsylvania Court } \\
\text { House }^{*} \\
\end{array}$ & 8-21 May 1864 & 100,000 & 52,000 & $18 \%$ & $23 \%$ \\
\hline $\begin{array}{c}\text { Battle of Cold } \\
\text { Harbor } \\
\end{array}$ & $\begin{array}{c}\text { 31 May-12 } \\
\text { June } 1864\end{array}$ & 108,000 & 62,000 & $11.8 \%$ & $7.4 \%$ \\
\hline \multicolumn{6}{|c|}{ Western Theatre } \\
\hline Battle of Perryville & 8 Oct 1862 & 20,000 & 16,000 & $21 \%$ & $21.3 \%$ \\
\hline $\begin{array}{c}\text { Battle of Stones } \\
\text { River* }\end{array}$ & $\begin{array}{c}31 \text { Dec } 1862-2 \\
\text { Jan } 1863\end{array}$ & 41,400 & 35,000 & $31.2 \%$ & $33.5 \%$ \\
\hline $\begin{array}{c}\text { Battle of Champion } \\
\text { Hill }\end{array}$ & 16 May 1863 & 32,000 & 22,000 & $7.7 \%$ & $17.5 \%$ \\
\hline $\begin{array}{c}\text { Battle of } \\
\text { Chickamauga }\end{array}$ & $\begin{array}{c}18-20 \text { Sep } \\
1863 \\
\end{array}$ & 60,000 & 65,000 & $27 \%$ & $28.4 \%$ \\
\hline
\end{tabular}

\footnotetext{
* indicates battle associated with "Home, Sweet Home” event
} 
Bibliography

Abe, Ernest L. “’Home, Sweet Home’: A Civil War Soldier’s Favorite Song.” America’s Civil War, (May 1996). http://www.historynet.com

AmericanCivilWar.com “Civil War Music History and Songs.”

http://www.americancivilwar.com/Civil_War_Music/civil_war_music.html

Beidler, Philip D. Late Thoughts on an Old War. Athens, Georgoa: University of Georgia Press, 2004.

Brader, Ted. "Striking a Responsive Chord: How Political Ads Motivate and Persuade Voters by Appealing to Emotions." American Journal of Political Science, Vol. 49, No. 2, (April 2005): 388-405.

Capra, Monica. "Mood-Driven Behavior in Strategic Interactions." The American Economic Review, Vol. 94, No. 2, Papers and Proceedings of the One Hundred Sixteenth Annual Meeting of the American Economic Association. (May, 2004), 367-372.

Ettlinger, Harold. The Axis on the Air. New York, New York: The Bobbs-Merrill Company, 1943.

Goodman, Steve. Sonic Warfare: Sound, Affect and the Ecology of Fear. London, England: The MIT Press, 2010.

Hale, Julian. Radio Power: Propaganda and International Broadcasting. Philadelphia, PA: Temple University Press, 1975.

Kellett, Anthony. Combat Motivation: The Behavior of Soldiers in Battle. Boston: Kluwer Nijhoff Publishing, 1982.

Kindsvatter, Peter S. American Soldiers: Ground Combat in the World Wars, Korea and Vietnam. Lawrence, Kansas: University Press of Kansas, 2003.

Maslow, Abraham H. Motivation and Personality. New York: Harper \& Row Publishers, 1954.

Perone, James E. Songs of the Vietnam Conflict. Westport Connecticut: Greenwood Press, 2001.

Smith, Kathleen, E.R. God Bless America: Tin Pan Alley Goes to War. Lexington, KY:

University Press of Kentucky, 2003.

Sizer, Laura. "Moods in the Music and the Man: A Response to Kivy and Carroll." The Journal of Aesthetics and Art Criticism Vol. 65, No. 3, (June, 2007), 307-312.

The Civil War Preservation Foundation's website http://www.civilwar.org

Trotter, William R. “The Music of War.” Military History Magazine (June 2005). http://www.historynet.com/the-music-of-war.htm 
Watkins, Glenn. Proof through the Night: Music and the Great War. Los Angelos, CA:

University of California Press, 2003.

Weintraub, Stanley. Silent Night: The Story of the World War I Christmas Truce. New York, NY: The Free Press, 2001.

Williams, Alfred M. "Folk-Songs of the Civil War.” The Journal of American Folk-lore Vol V (October 1892).

Zernich, Gordon. “Adrian Cronauer: Air Force Radio Annoucer in Vietnam.” Vietnam Magazine, (Feb 2001). http://www.historynet.com 